\title{
Archaeological Investigations at the Navarro Street Parking Garage, San Antonio, Texas
}

Anne A. Fox

A. Nightengale

I. Waynne Cox

Follow this and additional works at: https://scholarworks.sfasu.edu/ita

Part of the American Material Culture Commons, Archaeological Anthropology Commons, Environmental Studies Commons, Other American Studies Commons, Other Arts and Humanities Commons, Other History of Art, Architecture, and Archaeology Commons, and the United States History Commons

Tell us how this article helped you.

This Article is brought to you for free and open access by the Center for Regional Heritage Research at SFA ScholarWorks. It has been accepted for inclusion in Index of Texas Archaeology: Open Access Gray Literature from the Lone Star State by an authorized editor of SFA ScholarWorks. For more information, please contact cdsscholarworks@sfasu.edu. 


\section{Archaeological Investigations at the Navarro Street Parking Garage, San Antonio, Texas}

\section{Creative Commons License}

(c) (i) (8)

This work is licensed under a Creative Commons Attribution-NonCommercial 4.0 International License 


\section{ARCHAEOLOGICAL INVESTIGATIONS AT THE \\ NAVARRO STREET PARKING GARAGE, SAN ANTONIO, TEXAS}

Anne A. Fox, Bruce A. Nightengale, and I. Waynne Cox

Center for Archaeological Research

The University of Texas at San Antonio

Archaeological Survey Report, No. 174 





\section{ARCHAEOLOGICAL INVESTIGATIONS AT THE \\ NAVARRO STREET PARIKING GARAGE, SAN ANTONIO, TEXAS}

Anne A. Fox, Bruce A. Nightengale, and I. Waynne Cox

Center for Archaeological Research The University of Texas at San Antonio(i) Archaeological Survey Report, No. 174 
The following information is provided in accordance with the General Rules of Practice and Procedure, Chapter 41.11 (Investigative Reports), Texas Antiquities Committee:

1. Type of investigation: archaeological testing;

2. Project name: Navarro Street Parking Garage;

3. County: Bexar County, Texas;

4. Principal Investigator: Thomas R. Hester; Co-Principal Investigators: Jack D. Eaton and Anne A. Fox;

5. Name and location of sponsoring agency: City Public Service, San Antonio, Texas;

6. Texas Antiquities Committee Permit No. 607;

7. Published by the Center for Archaeological Research, The University of Texas at San Antonio, San Antonio, Texas 78285-0658, 1988.

A list of publications offered by the Center for Archaeological Research can be obtained by sending $\$ 1.00$ to the Center for Archaeological Research, The University of Texas at San Antonio, San Antonio, Texas 78285-0658. 


\begin{abstract}
In March 1987, the Center for Archaeological Research of The University of Texas at San Antonio conducted test excavations on Lot 1 of New City Block 125 in downtown San Antonio. The purpose of the excavations was to determine if any remains of foundations or artifactual deposits were still intact beneath the surface, in preparation for the construction of an addition to a parking garage. A search was also made for remains of the Concepción Acequia that once formed the western boundary of the lot. Three backhoe trenches ranging from 42 to 90 feet in length and from 26 to 88 inches in depth determined that while the foundation of a two-story brick commercial building appeared to be intact, none of the original ground surface was undisturbed, and no historic features would have been preserved. No confident identification could be made of the acequia because of numerous later disturbances in the area.
\end{abstract}




\section{TABLE OF CONTENTS}

ABSTRACT $\ldots \ldots \ldots \ldots \ldots \ldots \ldots \ldots \ldots \ldots \ldots \ldots \ldots \ldots \ldots \ldots \ldots \ldots \ldots \ldots$

LIST OF FIGURES $\ldots \ldots \ldots \ldots \ldots \ldots \ldots \ldots \ldots \ldots \ldots \ldots \ldots \ldots \ldots \ldots \ldots \ldots$

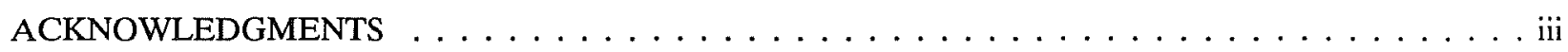

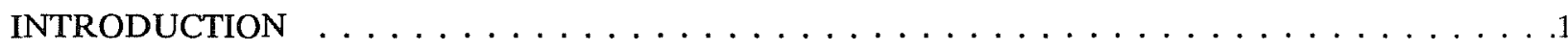

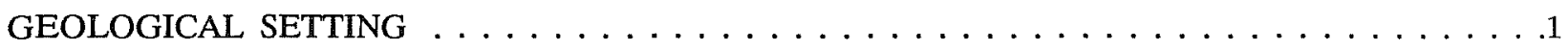

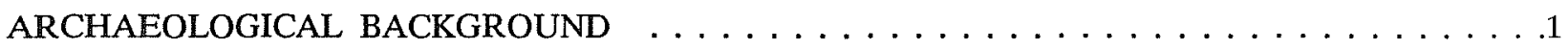

NAVARRO STREET GARAGE PROPERTY HISTORY $\ldots \ldots \ldots \ldots \ldots \ldots \ldots \ldots$

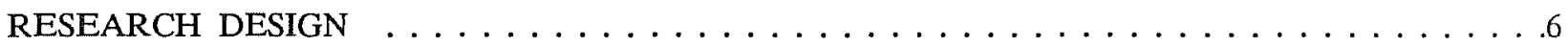

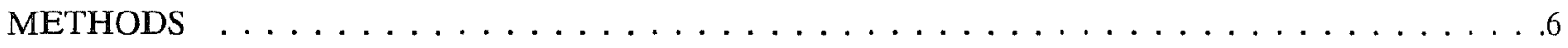

INVESTIGATIONS $\ldots \ldots \ldots \ldots \ldots \ldots \ldots \ldots \ldots \ldots \ldots \ldots \ldots \ldots \ldots \ldots \ldots \ldots$

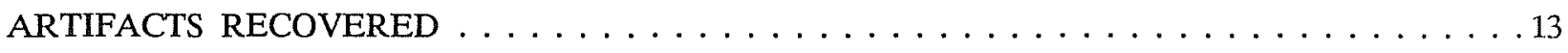

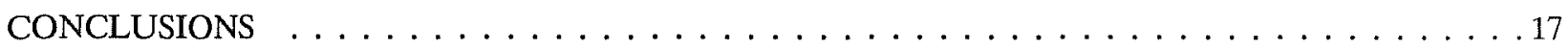

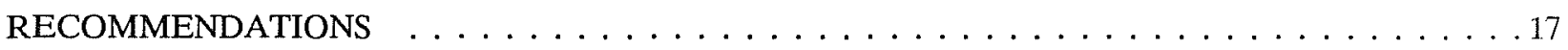

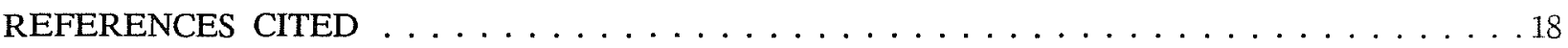

\section{LIST OF FIGURES}

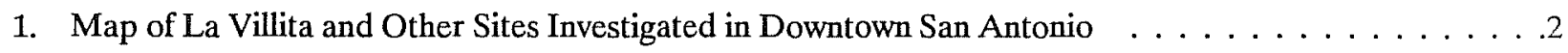

2. Civil War Map of San Antonio Showing Location of Dam and Acequia $\ldots \ldots \ldots$

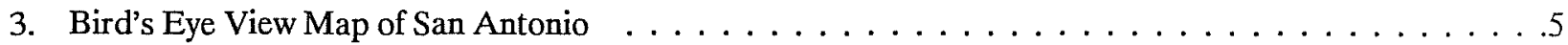

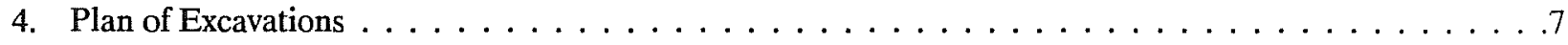

5. Section of 1904 Sanborn Insurance Map $\ldots \ldots \ldots \ldots \ldots \ldots \ldots \ldots \ldots \ldots \ldots \ldots \ldots \ldots \ldots$

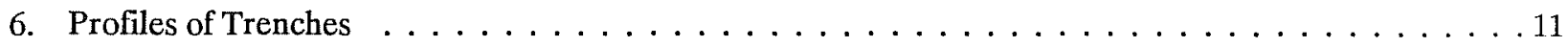

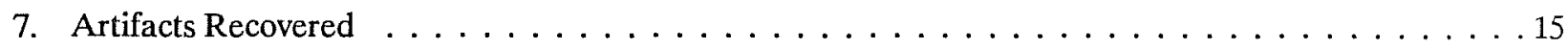




\section{ACKNOWLEDGMENTS}

We wish to acknowledge the help of Laurence Raba of Cerna Raba Architects and Roy West of Roy G. West and Associates, Inc., for their help in planning and expediting this project.

The crew included Bruce Nightengale as crew chief, David Turner, Jeff Huebner, and Kelly Scott. Waynne Cox did the historical and archival research for the project. Drafting was done by Bruce Ellis and Cathy Dodt-Ellis of the Center staff. Sharon Quirk was the editor, and Mary Lou Ellis was the typist for the report. 



\section{INTRODUCTION}

In March 1987, the Center for Archaeological Research (CAR) of The University of Texas at San Antonio (UTSA) conducted test excavations on Lot 1 of New City Block (NCB) 125 in the section of downtown San Antonio called La Villita. The work was done in preparation for the total removal of this lot during construction of a below-grade addition to the Navarro Street Parking Garage. The property belongs to City Public Service of San Antonio, and is located within La Villita Historic District Expansion of 1975 (City Historic Preservation Office, personal communication). The project was conducted under Texas Antiquities Committee Permit No. 607. State trinomial number 41 BX 648 has been assigned to the site by the Texas Archeological Research Laboratory (TARL) in Austin.

Principal investigator for the project was Dr. Thomas R. Hester, director of the Center. Co-principal investigators were Jack Eaton and Anne Fox. Approximately 100 person hours were expended during the field work by a crew composed of UTSA students under the direction of Fox.

All research notes, field and laboratory records, photographs, and artifacts from this project are curated at the laboratory of the Center for Archaeological Research at The University of Texas at San Antonio.

The lot in question is part of a paved parking lot at the corner of Villita and South Presa Streets. A multistory parking garage stands on the west edge of the lot. The San Antonio River currently runs east to west half a block to the north of the property. The restored section of La Villita is located across South Presa Street to the east of the lot.

\section{GEOLOGICAL SETTING}

La Villita is located on a terrace of the San Antonio River at an elevation of ca. 645 to 650 feet above mean sea level (MSL). The present surface of the site slopes about one degree from east to west. The elevation there is lower than at the intersection of South Alamo and Villita Streets, which probably in the past has caused drainage from the eastern portion of La Villita occasionally to cross the site. Although the land on this side of the river is slightly higher than that within the river bend where the first settlement was built, NCB 125 apparently was sufficiently inundated during the 1819 flood to cause some destruction and abandonment of homes (Ivey 1978:4).

The natural soil beneath the structures in La Villita is a compact, dark gray brown clay loam (Fox, Valdez, and Bobbitt 1978:Fig. 7; Ivey 1978:Fig. 4; Brown 1986:28), referred to by Taylor, Hailey, and Richmond (1966:21) as Houston Black clay. Below this soil is a layer of calcareous sediments locally called caliche, which grades into white chalky marl (Brown 1986:28).

\section{ARCHAEOLOGICAL BACKGROUND}

A number of archaeological investigations have been done in La Villita. Three of these were done in relation to standing structures, and two in preparation for new construction. In each case, the related historical and archaeological research has contributed to a growing body of information on the area of La Villita.

In 1969, Mardith Schuetz of the Witte Museum conducted excavations within a stone ruin on NCB 155. This was thought to be the site of a cuartel (Fig. 1), or military barracks, that apparently was built in the vicinity, ca. 1809 (Schuetz 1970:3). The ruins were found to be those of a late 19th-century stable. However, Schuetz (1970:39) speculated that the walls of the stable could have originally been part of the cuartel. The exact location of the cuartel has not as yet been positively identified.

Personnel from the CAR-UTSA conducted archaeological testing on NCB 901 and NCB 155 in 1976 (Katz 1978). The excavations, directed by Paul Katz, located a number of foundations of early houses and explored a cistern 


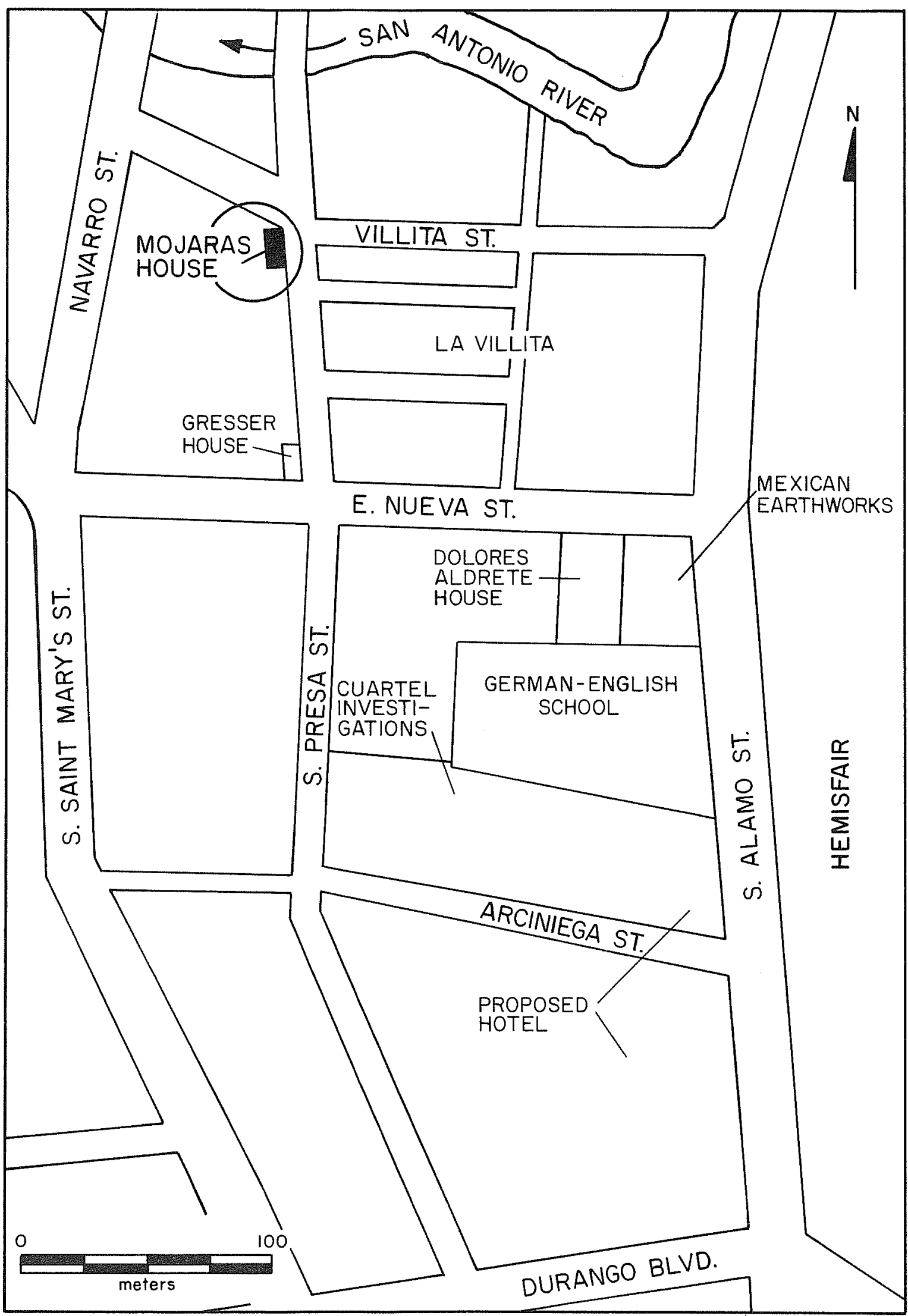

Figure 1. Map of La Villita and Other Sites Investigated in Downtown San Antonio. Circled area in vicinity of Mojaras house indicates project area. 
and a privy related to these houses. The work was done in preparation for the construction of a multistory hotel on the property.

In 1977, archaeologists from the CAR-UTSA, directed by James Ivey, investigated an area immediately south of and adjoining the Gresser house (Fig. 1), which is several lots south of Lot 1 on NCB 125. Ivey (1978) examined and recorded foundations of an early 19th-century house, and reconstructed the complete history of the buildings on the lot.

Test excavations in 1978 at the Dolores Aldrete house (Fig. 1) and Caile house on Lots 7, 8, and 9 of NCB 155 were directed by Daniel E. Fox for the CAR-UTSA (Fox, Valdez, and Bobbitt 1978). The project recovered artifactual and architectural information.

While monitoring the excavation of a basement for a hotel on Lot 6 of NCB 155 in 1985, Joe Labadie of the CARUTSA recognized a deposit of early 19th-century artifacts. Subsequent archaeological investigations revealed a trench originally related to Mexican earthworks (Fig. 1) used in the Battle of the Alamo in 1836 (Labadie 1986). The trench had later been filled with neighborhood trash. Numerous fragments of arms and munitions from the battle were recovered, as well as an important collection of early 19th-century household artifacts.

As the result of these excavations, much historical and artifactual information related to the area of La Villita has been recovered. It was hoped that the test excavations at the Navarro Street Parking Garage would add to this information.

\section{NAVARRO STREET GARAGE PROPERTY HISTORY}

Lot 1 on NCB 125 was originally a portion of the lands of San Antonio de Valero, referred to since Spanish colonial times as "La Villita." It was located at the major ford of the San Antonio River between the presidio and villa on the west side and Mission San Antonio de Valero on the east bank (Ramsdell 1976:110). Above this ford the dam for the Pajalache or Concepción Acequia was constructed ca. 1729 (Corner 1890:43; Arneson 1921:123), and from this point, the deeply cut channel of the acequia formed the western boundary of the present lot $(B C D R$ Vol. W1:422). With the secularization of the mission lands in 1793, the property encompassed on the north and west by the San Antonio River, the road to the lower missions (South Alamo Street) on the east and to a point north of present Nueva Street on the south, was granted by the Spanish government to the heirs of Manuel Antonio Losoya. Losoya was a lieutenant at Presidio Los Adaes in east Texas (Spanish Archives Vol. 3:302; Chabot 1937:219), and was one of the Los Adaes refugees who settled in the vicinity of Mission Valero in the mid-18th century.

The area was slow to develop until the great flood of 1819 swept away much of the town, and the bluff on which La Villita sat began to attract resettlement (Ramsdell 1976:110). In April 1847, P. L. Buquor, county clerk for many years and mayor from 1863 to 1865 , purchased three lots, seized by the county for back taxes, that had belonged to the "heirs of Losoya" (Buck 1980:285; BCDR Vol. E2:116). The lots were situated along what is now Villita Street between South Alamo Street and the Concepción Acequia, with a frontage on the street of 60 varas (166.6 feet). Twenty-four days later, Buquor conveyed the property to Thomas Newcomb (BCDR Vol. E2:249). In September of the same year, Newcomb sold Lot 1 to José María Mojaras for $\$ 50$ (BCDR Vol. F2:238). The 1850 census (USDIOC 1850) indicates that Mojaras, a butcher 43 years of age, residing with his wife, Concepción, and Benito Monjaras (probably a misspelling), age 8 , possessed $\$ 200$ in real estate (USDI-OC 1850). Mojaras evidently constructed the house soon after he purchased the property.

Subsequent flooding on the river resulted in public pressure to remove the Concepción dam in 1869 as an obstruction to river flow (Corner 1890:43). The city council approved its removal in March 1870 (CCM:March 23, 1870), and the next month ordered the open ditch to be refilled (CCM:April 11, 1870). By 1873, all traces of the ditch north of South Alamo Street had been obliterated (Figs. 2, 3).

In 1870, Concepción Ruiz de Mojaras was occupying the structure on Lot 1 when she sold a portion to the owner of Lot 2, Joseph Deutz (BCDR Vol. V2:293). A later sale of Lot 2, in 1888, indicated that she ceased to occupy 


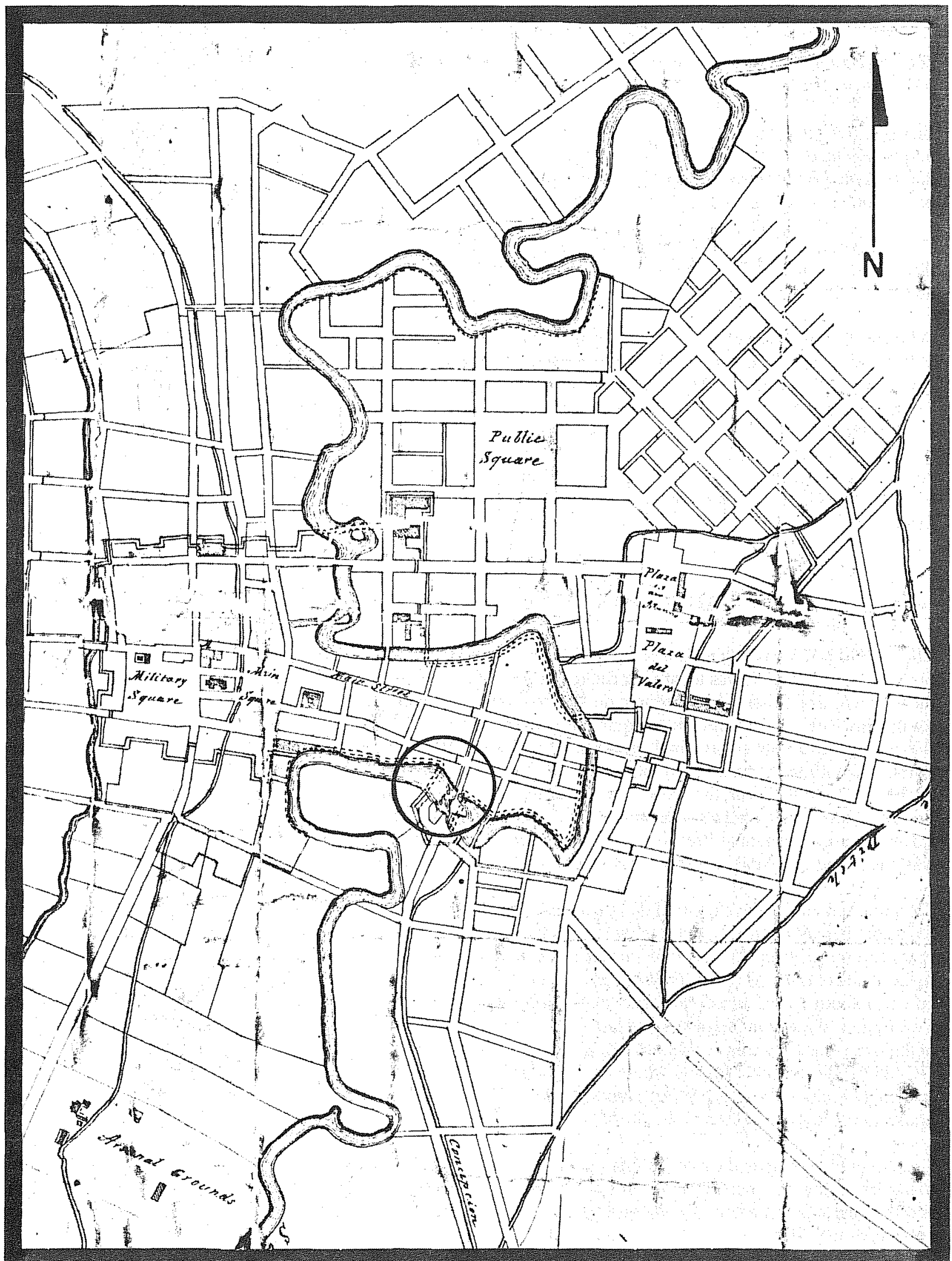

Figure 2. Civil War Map of San Antonio Showing Location of Dam and Acequia. Area of the dam and acequia is indicated by circle. 


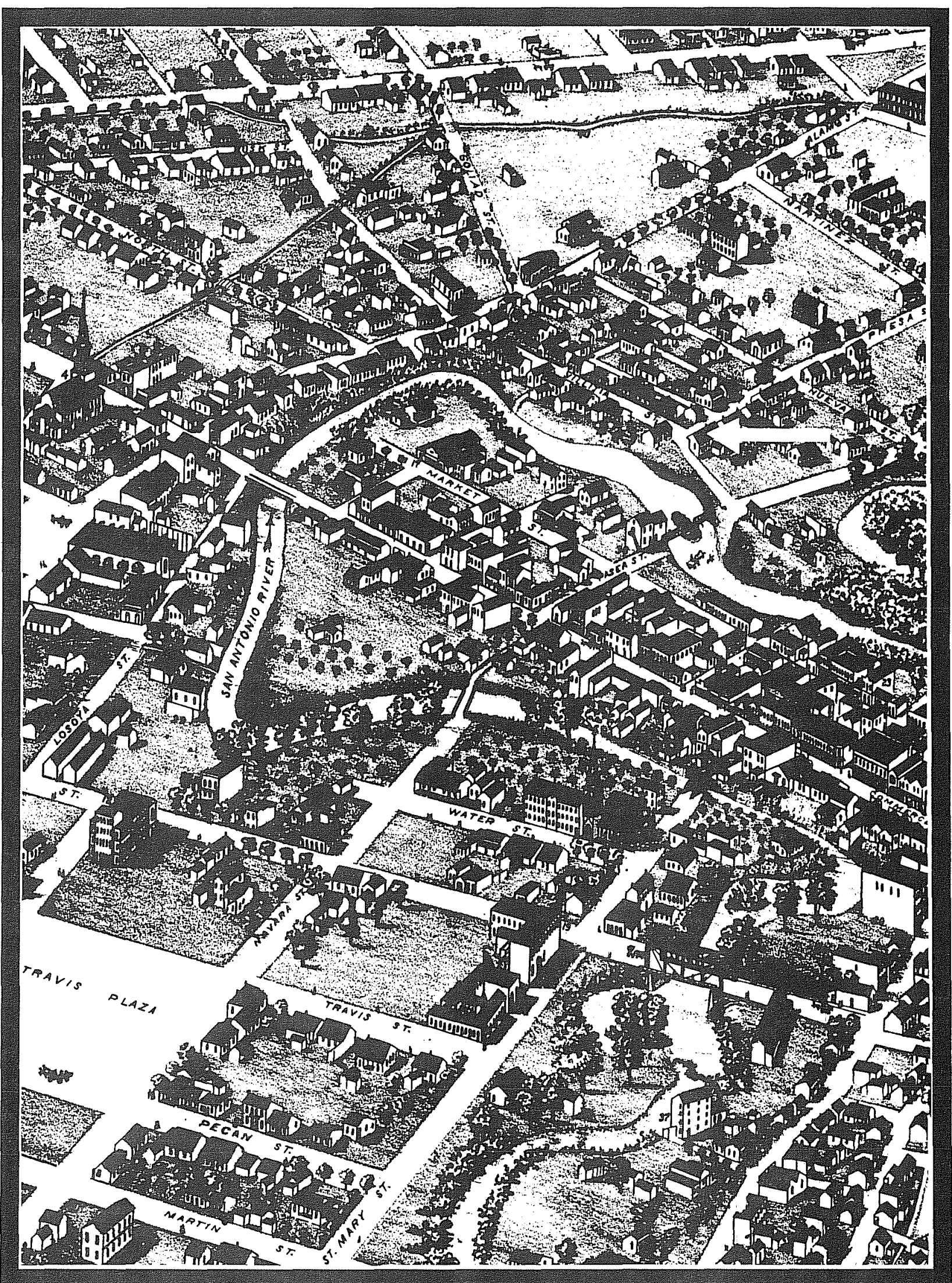

Figure 3. Bird's Eye View Map of San Antonio. Taken from Koch (1873). View toward the southeast; arrow indicates location of project area. 
the property beyond $1870(B C D R$ Vol. 50:557). The archival records are silent on who acquired the property from the Mojaras heirs. By 1877, the building on the lot was rented by Michael Eckenroth, a carriage maker and blacksmith (City Directory 1881-1882). By 1904, a two-story brick building stood on the lot (Sanborn Map and Publishing Company, Ltd. 1904). The records fail to indicate when the brick structure was introduced, but considering the space requirements for a carriage maker, it may have been constructed prior to the occupation by the carriage maker in 1877.

By 1905, the brick structure housed the Tripis Kraut Works, a branch of the G. C. Tripis Company (City Directory 1905-1906). From 1909 to 1914, it was the home of the San Antonio Sheet Metal Works (City Directories 19091914). From 1917 to 1922 , the records indicate the building was vacant, but by 1934 to 1937 , it was occupied by the Lucus Sheet Metal Works (City Directories 1917-1937). In 1942, the building was again vacant, and in 1946, housed the Pentecostal Church of God (City Directories 1942-1946). From 1948 to 1951, it housed the business and residence of Samuel E. Neiman, contractor, and his wife, Miriam (City Directories 1948-1951).

The next available information on the ownership of Lot 1 is in 1951, when it was inherited by Fred Goeth from the estate of his father, C. A. Goeth. This would seem to imply that ownership could have been in the Goeth family for a number of years. From 1955 to 1958, the building was occupied by Mickey's Place Beer, until its demolition in the fall of 1958 when the property was purchased from Fred Goeth by City Public Service (BCDR Vol. 4209:425; City Public Service Board 1958).

In summary, it appears that two successive buildings have stood on Lot 1 . The first was a one-story, soft rock or "adobe" residence built by José María Mojaras ca. 1847. It closely resembled numerous other small La Villita houses built at about the same time. The south wall of this house was located 1-3/4 varas from the present south line of Lot 1 (Fig. 4; BCDR Vol. V2:293). Based on observations of similar structures in San Antonio, the foundations would have consisted of roughly shaped limestone blocks set in mud, sand, or sand and lime mortar.

The second building on the lot was a two-story brick commercial building, possibly built as early as 1877 , but documented to be in place by 1904 . The 1904 Sanborn insurance map (Fig. 5) shows the south wall of this building much farther north than that of the earlier house, in fact close to the center of the lot. Such buildings in San Antonio generally had brick or cut limestone foundations. Cement for mortar in any quantity was not readily available locally until after the establishment of the Alamo and Portland Cement Company in Brackenridge Park in January 1880 (Baumburger n.d.). If the building was built before this time, the foundations probably were set in lime and sand mortar.

\section{RESEARCH DESIGN}

The principal question to be answered by the project was whether any structural or artifactual evidence of the Mojaras or later occupations had been preserved intact beneath the surface of Lot 1 . It was also necessary to establish whether some evidence could be found of the east bank of the Concepción Acequia. Incidental to the main intent of the investigation, but also of interest to the history of the lot, is the question of when the two-story brick building replaced the Mojaras house. The first two questions could be answered by examining the walls and sampling the contents of the test trenches. The answer to the third question could be deduced, primarily, from examining any existing remnants of walls, wall materials, and foundations found during the trenching.

\section{METHODS}

Three backhoe trenches ca. two feet wide and of varied length, orientation, and depth were used to assess the subsurface location and integrity of remnant wall foundations from the two known structures on the site, as well as to search for indications of the Concepción Acequia. Based on early maps of the site and the known dimensions and orientation of the Gresser house (41 BX 369), it was established that the foundations of the Mojaras house and the later two-story brick building should be found on the eastern portion of the lot (Fig. 4). Probable outbuildings, 


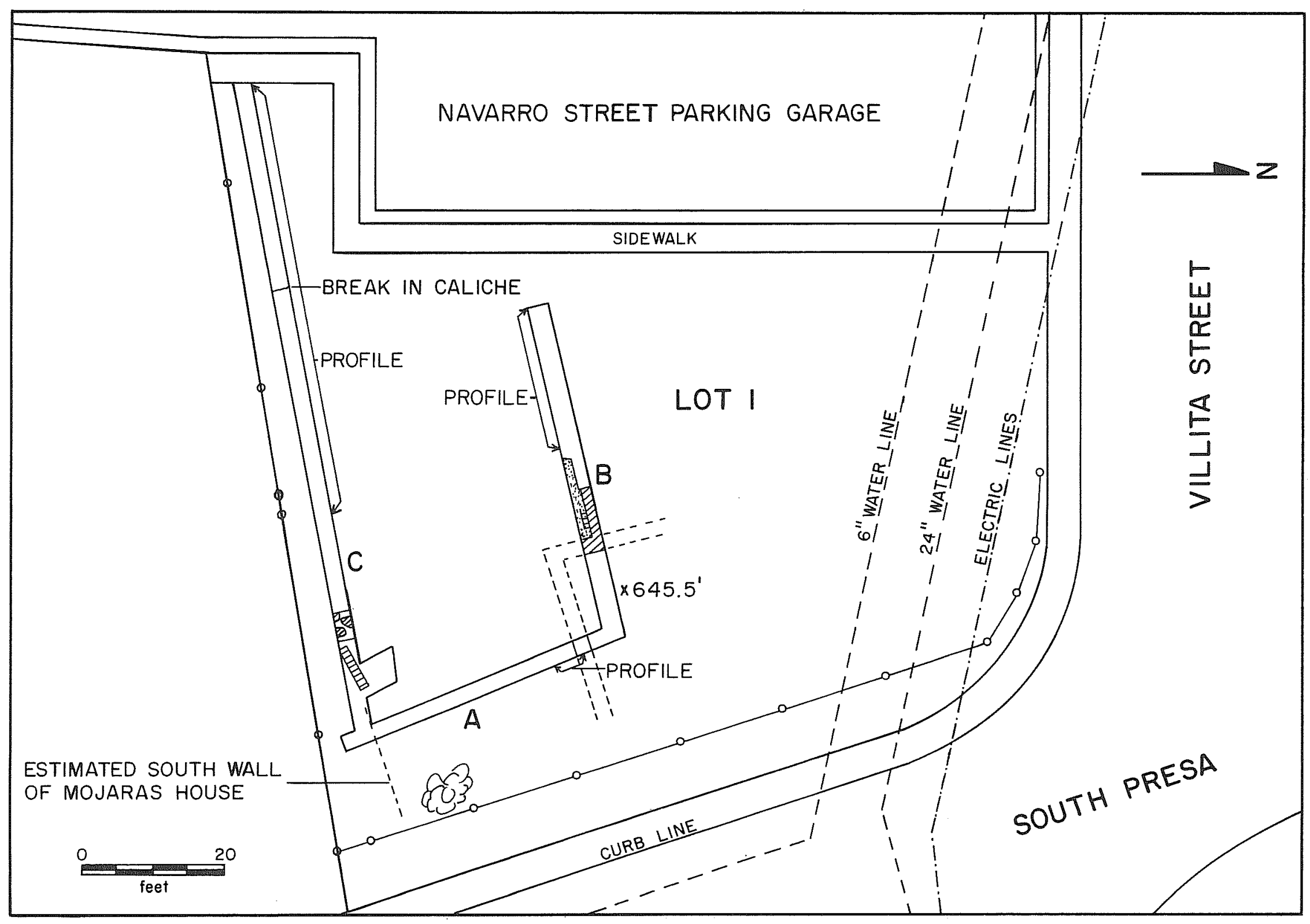

Figure 4. Plan of Excavations. Trenches A, B, and C are indicated. 


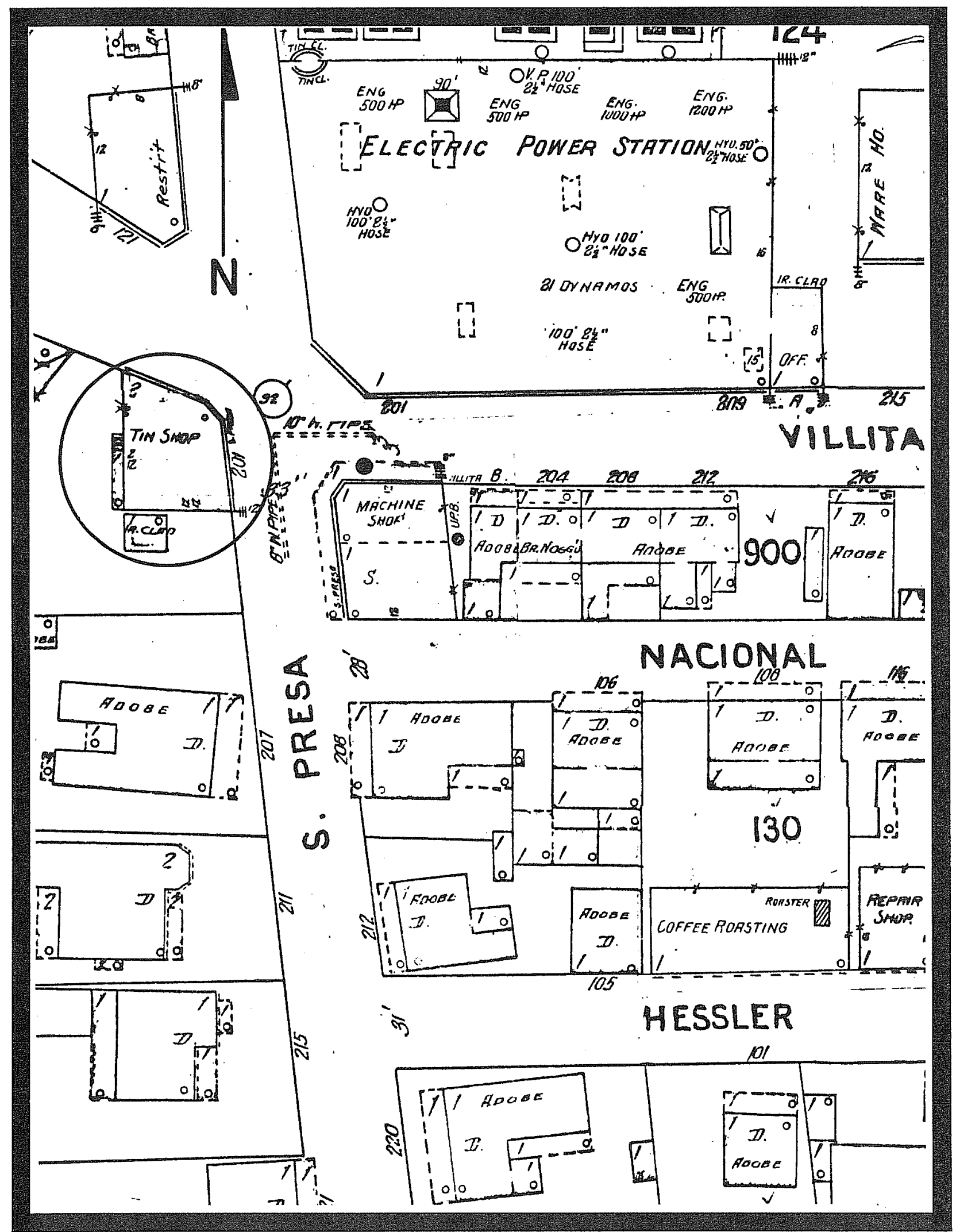

Figure 5. Section of 1904 Sanborn Insurance Map. Taken from Sanborn Map and Publishing Company, Ltd. (1904). Circle indicates project area. 
utility structures, trash disposal areas, cisterns or wells would be located on the western part of the lot. Also, utilizing maps and earlier research in the area, the location of the acequia was estimated to be along the western line of the lot. Here, it was hoped that remains of the acequia's left bank might still be discernible below the surface, as the majority of the ditch is probably overlain by the parking garage.

The hypothesized location of these cultural features dictated the placement and alignment of backhoe trenches. Trench A was used to crosscut any east-west foundations. Trench B, east end, was used to search for the northsouth walls of any structures on the lot, while the west end was used to search for features in the back yard and for the bank of the acequia. Trench C, east end, assessed the area bordering the south end of Trench A in the vicinity of the south wall of the Mojaras house, while the west end was used to test for the acequia and for any utility features connected with the occupation of the lot. Trenches were excavated to sterile deposits or, in the case of the west end of Trench C, deep enough, in the judgment of the field director, to recover the needed information.

The use of a backhoe for test trenching has been established as an economical and efficient method for the investigation of stratigraphy and artifact content beneath paved parking areas in San Antonio (Katz 1978; Fox 1978a; Ellis 1986). The methods employed for documentation of exposed features and stratigraphy included drawing profiles of selected segments of trench walls, taking soil samples from specific profiles for later analysis, and making photographs and plan drawings of the features. A site map was drawn with the aid of pocket transit and tape, utilizing blue line maps of the site provided by the architects. Selected artifacts were collected from trench walls and backdirt as representative samples.

\section{INVESTIGATIONS}

Brief descriptions of the trenches and what was found in each one are presented. For trench locations see Figure 4.

\section{TRENCH A}

In an attempt to crosscut foundations, Trench A was oriented south to north along the eastern portion of the parking lot. It ran parallel to South Presa Street through the highest portion of the site. The trench was 42 feet in length and 26 inches in width with depths of between 26 and 40 inches. The bottom of the trench lay within a hardpacked caliche stratum that forms the lowest of nine strata identified in the trench. Six short profiles of sections of the east and west trench walls indicated a thick gray brown rubble-filled stratum underlying parking lot asphalt and fill, overlying culturally sterile strata and caliche below (Fig. 6). Singular and apparently undisturbed layers within the rubble fill suggest different depositional episodes associated with past demolition and construction activities at the site. The mixed nature of artifacts within the rubble fill did not allow any discrete ordering of strata. The artifacts are typical of demolition debris - varied quantities of white earthenware, glass container fragments, red and yellow brick fragments and crumbling mortar, pieces of concrete, tile, nails, pieces of metal, and window glass. Ash and wood scraps were observed in the trench walls.

One of five pipe trench disturbances at the site was observed at 16 to 30 inches below the surface in the north end of the trench, oriented east-west. About three feet north of the pipe trench lay a dressed limestone foundation block 24 inches in width and approximately 20 inches in height. The lower portion rested within the caliche stratum, and disturbance in the vicinity indicated that other similar blocks had been removed. The block was set in soft sand and lime mortar. Its location, surface treatment, and mortar remains suggested that it was the wall foundation for the two-story brick structure. The surrounding demolition fill contained numerous yellow brick fragments and chunks of the same mortar. This type of brick was not available in San Antonio until the arrival of the railroads in the early 1870s, which sparked a surge in construction of downtown buildings in yellow brick. Mortar of lime and sand was in common use in San Antonio until the opening of the cement plant in Brackenridge Park in 1880. This suggests that one of the reasons for acquiring the lot in La Villita from the Mojaras family in the 1870s was to build a commercial building for lease. 
Figure 6. Profiles of Trenches.

\section{Trench A - East Wall}

1 - black asphalt paving

2 - gravel base (10 YR 7/8)

3 - grayish brown (10 YR 5/2) clay loam

4 - pinkish white (5 YR 8/2) mortar

5 - light brownish gray (10 YR 8/2) mortar

6 - white (10 YR 8/2) caliche

7 - light brownish gray (10 YR 6/2) sandy loam

8 - white (10 YR $8 / 2$ ) caliche

9 - very pale brown (10 YR 8/3) caliche

\section{Trench B - South Wall}

1 - black asphalt paving

2 - gravel base (10 YR 7/8)

3 - black asphalt paving

4 - gravel base (10 YR 6/4)

5 - very pale brown (10 YR 4/1) sandy loam

6 - dark gray (10 YR 4/1) with rubble and trash

7 - dark grayish brown (10 YR 4/2) clay loam 8 - white (10 YR 8/2) caliche

9 - dark grayish brown (10 YR 4/2) clay loam

\section{Trench C - North Wall}

1 - black asphalt paving

2 - gravel base (10 YR 7/8)

3 - black asphalt paving

4 - gravel base (10 YR 6/4)

5 - dark gray (10 YR 4/1) clay loam

6 - dark gray (10 YR 4/1) with rubble and trash

7 - dark grayish brown (10 YR 4/2) in pipe trenches 8 - white (10 YR 8/2) caliche

9 - dark grayish brown (10 YR 4/2) clay loam 


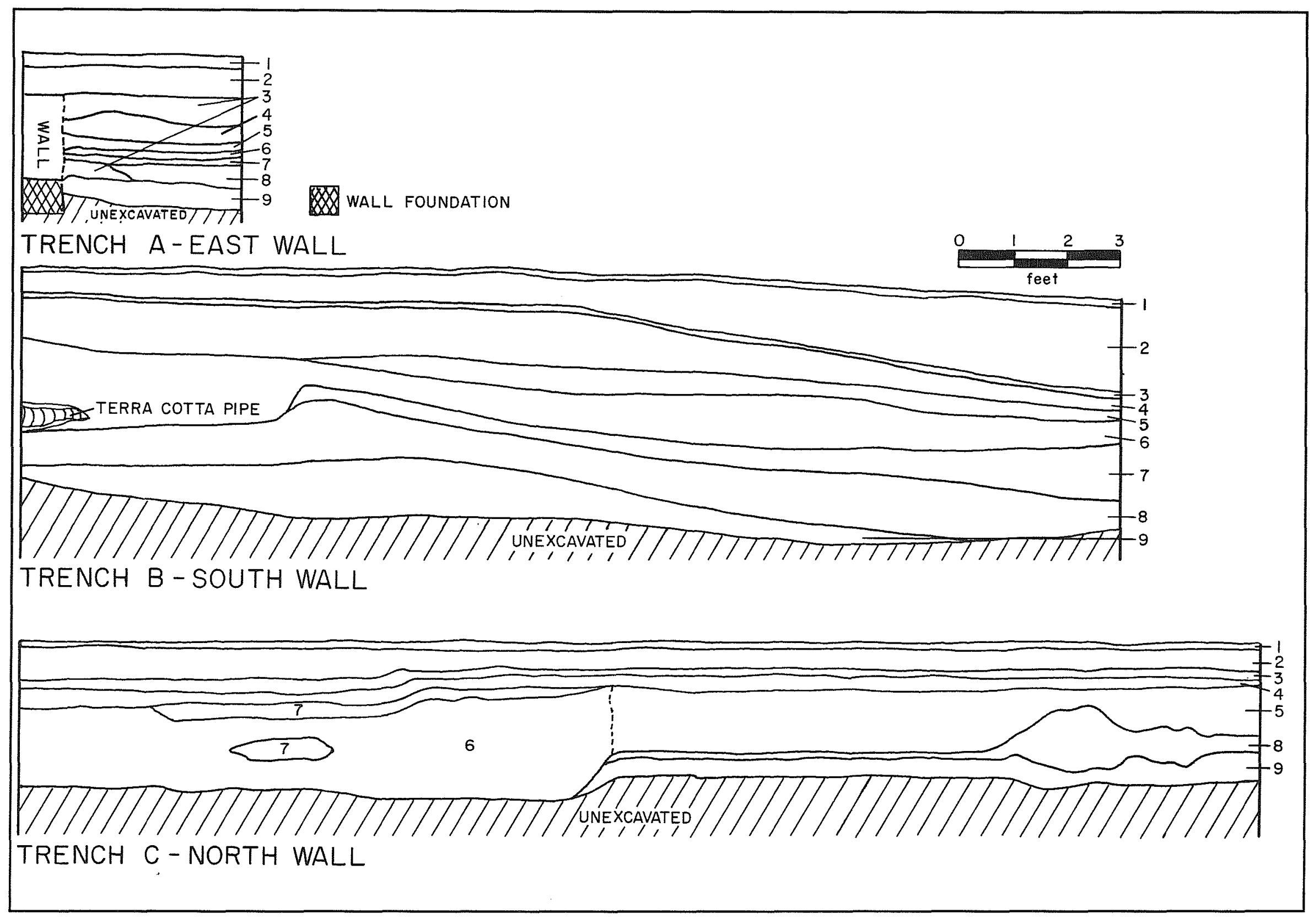


Careful examination of the south end of Trench A failed to reveal the foundation for the Mojaras house, despite the fact that the trench crossed the probable line of the foundation. A few large, unshaped limestone blocks that may have come from the house foundation were taken from that end of the trench but were not in situ.

\section{TRENCH B}

Using the location of the limestone foundation in Trench A as a guideline, Trench B was oriented west from the north end of Trench A to locate the west wall foundation of the building and assess the western portion of the lot. The trench was 46 feet in length, 30 inches in width, and between 47 and 51 inches in depth. The strata in Trench $B$ dipped west with the slope of the surface. The nine different strata differed from those observed in Trench A (Fig. 6). The upper strata are composed of two sequences of parking lot construction. Except for color gradations, the middle rubble-filled cultural stratum is undifferentiated, while the lower hard-packed caliche surface found in Trench A was not present. Instead, an unconsolidated 8- to 10-inch-thick, culturally sterile stratum with high calcium carbonate content was observed overlying a sterile dark brown alluvium in the bottom of the trench. Artifacts observed and collected from the rubble fill were similarly mixed from past demolition and construction activities. Artifacts from Trench B were undecorated ceramic sherds, glass container fragments, a religious medal, red and yellow brick, window glass, metal scraps, and fragments of tile.

Two north-south ceramic pipe trenches were observed in the western area of the trench. One was located 20 feet from the west end of the trench at 30 inches below the surface, where it truncated the lower two strata. The other was situated approximately 21 inches from the juncture of Trenches A and B at about the same depth as the first. This second pipe trench underlay the western overhang of a poured concrete slab anchored on the west side of a dressed limestone foundation similar to the one which crossed Trench A north-south. The dressed limestone feature was 66 inches in width and 40 inches in depth. A north-south seam was found 24 inches from the east edge, indicating the outer face of the back wall of the two-story brick structure. The additional limestone on the back of the foundation apparently was related to an architectural feature in this area, perhaps the base of the stairway to the second floor. Portions of the south edge of this limestone protrusion had been chiseled away to accommodate the eight-inch-thick concrete slab. Mortared onto the surface of this slab, perpendicular to the back wall of the structure, was the bottom section of a cinder block ca. 6 by 22 inches that originally had three cells. This was probably part of the base of some sort of 20th-century addition to the back of the building, for which the slab was a foundation. Cinder block made with three cells was in use in San Antonio ca. 1911 to 1934 (Henry Fox, personal communication). Embedded in the slab was a three-inch pipe with a flanged collar, set flush with the surface and extending through the slab into the fill beneath, above the pipe trench.

\section{TRENCH C}

Trench C extended west from the southern end of Trench A. It was used to investigate the southern area for foundations and the western area for evidence of the acequia. The trench was 90 feet in length, 26 inches in width, with depths of 50 inches at the east end and 88 inches at the west end. A 60-foot profile of the north wall at the west end showed nine strata. Except for one missing stratum and some color variations, these were somewhat similar to the strata exposed in Trench B. Similar were the two parking lot construction phases and the grayish brown rubble fill with varied artifact content. The underlying caliche in the eastern half of the trench was similar to that in Trench A, while the dark grayish brown alluvium that underlay the caliche was like that in Trench $\mathrm{B}$. The caliche stratum was visibly truncated 30 feet from the west end of the trench.

Artifact content within the rubble fill varied in density from east to west. The western 30 feet to the truncated caliche contained a relatively high density of debris, in comparison with the east end of the trench. Artifacts collected from this area were earthenwares, stoneware, glass, a clear glass bottle, a horseshoe, bone fragments, window and plate glass, tile fragments, pieces of metal, and painted plaster. The eastern end overlying the caliche stratum contained fewer, and on the whole, earlier artifacts.

Two pipe trenches were observed in the north wall profile about 10 feet from the western end. One lay 55 to 65 inches below the surface, oriented north to south, and the other lay 30 to 40 inches below the surface, oriented east 
to west. The latter trench was found in the upper part of the rubble stratum, while the former lay directly below it.

Further evidence of demolition and construction activities was seen in the eastern end of the trench about four feet from the juncture with Trench A. Here a 5 foot 9 inch long double course of yellow brick set in pinkish gray sandy mortar was exposed 30 inches below the surface, oriented at an angle from the north to south wall of the trench. The individual bricks were 4 by 8 by 2 inches. An area 74 by 48 inches was expanded to the north of the trench in hope of finding a corner or some other structural information, but none was found. Apparently this feature was a remnant of the brick structure that somehow remained intact during the demolition and leveling of the site.

About 10 inches west of the brick feature lay several limestone blocks surrounded by remnants of sand and mortar. These were approximately six inches deeper than the bottom of the brick feature. The blocks rested in a threefoot-wide depression in the underlying caliche surface that ran perpendicular to the line of Trench $\mathrm{C}$. This depression was too wide to have been a footing trench for the foundation of a one-story "adobe" house, and the stones appeared to have been disturbed, probably during the demolition of the Mojaras house.

The east bank of the Concepción Acequia was not readily apparent in the western end of Trench C. The area had been radically altered west of the truncation of the caliche stratum, but it was not possible to determine how much of this was the result of construction of the parking garage. The presence of ceramic pipe in preserved pipe trenches across the area suggests that it has not recently been disturbed. On the other hand, the artifacts recovered from the trench fill do not allow a confident statement that this fill was all deposited before the 1870 filling of the acequia. Of particular interest in this regard is a sherd of stoneware bearing a Bristol glaze, which did not come into use in San Antonio until ca. 1900 (Georgeanna Greer, personal communication), and fragments of electrical fixtures that could not have been in use locally until after 1882 (Schuchard 1951:31).

\section{ARTIFACTS RECOVERED}

The artifacts recovered are a random sample collected primarily from the walls and backdirt of the trenches as the excavations progressed. They can be roughly divided into personal and housekeeping items, pieces related to barn or workshop activities, and construction materials.

\section{RELIGIOUS MEDAL}

A thin, stamped metal object with a suspension loop mounted parallel to the face bears the image of the Virgin of Guadalupe and an embossed printing, "Ntra Sra DE GUADALUPE" in an indented, circular panel surrounded by a stylized wreath (Fig. 7,b). Two cherubs, one on either side of the virgin's head, appear to be holding an object above her. The whole is surrounded by a raised, hexagonal frame, the angles of which are rounded. The metal appears to be copper. The reverse side is unfinished and bears a reverse imprint of the design on the face as the result of the stamping process. The fact that the suspension loop is parallel to the face of the medal probably places the date of the object after 1800 (Richard Ahlborn, personal communication).

\section{CERAMICS}

Six earthenware sherds were recovered that probably are related to the Mojaras occupation because of their date of manufacture. In each case, the sherd was in a disturbed context, but all came from outside the foundation of the two-story brick building.

A fragment of a Mexican-made Galera ware chocolatera (Fig. 7,d), probably the earliest sherd in the collection, was found in the east end of Trench $\mathrm{C}$ at the level of the brick wall fragment. Several of these vessels were represented in the collection from the earthworks site on NCB 155 (Fox 1986:116), which suggests that they were still in use in San Antonio into the first half of the 19th century. 
Figure 7. Artifacts Recovered.

a, porcelain painted overglaze;

b, religious medal, Virgin of Guadalupe;

c, porcelain, gold painted overglaze;

d, earthenware chocolatera with lead glaze;

e, white earthenware with red transfer design;

f, white earthenware with blue shell edge design;

g, hand-blown wine bottle base;

h, stoneware with Leon slip from Meyer pottery. 


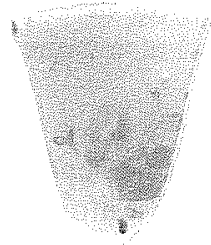

a

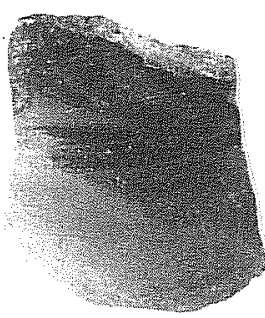

d

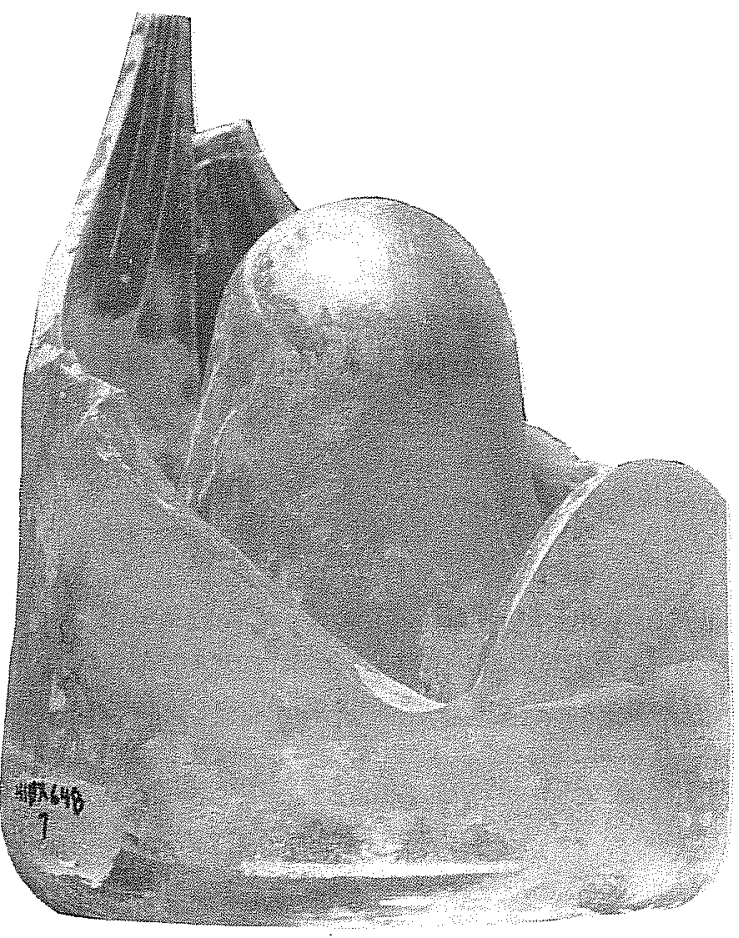

g

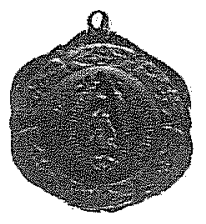

b

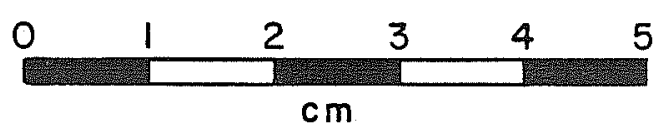

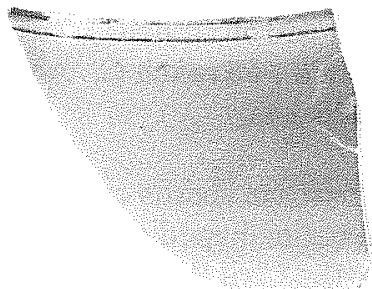

C
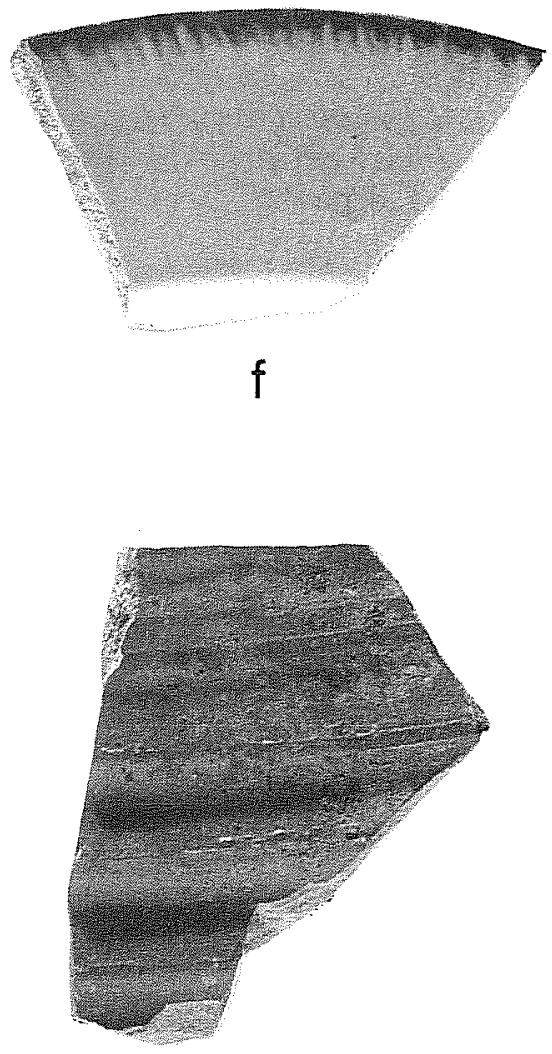

h

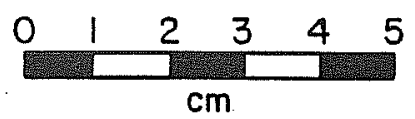


A very small sherd of blue hand-painted ware was found near the south end of Trench A near the bottom of the trench. A blue edgeware sherd (Fig. 7,f) came from among the limestone rubble below the level of the brick rubble in the east end of Trench C. Two red transfer-printed sherds (Fig. 7,e) were found among the disturbed deposits of the west end of Trench C. A rim sherd from an undecorated white earthenware bowl also came from these Trench C deposits.

Thirteen ironstone sherds came from the deeper deposits in Trenches B and C. Vessels represented are plates, cups, and a basin-shaped object designed to have a lid. Ironstone came into popularity in San Antonio immediately following the Civil War.

Four sherds of porcelain were collected from the excavations. One from a large fluted bowl is undecorated; two have gold bands painted over the glaze (Fig. 7,c); and one has a floral design painted over the glaze in pale blue, pink, and orange with gold touches (Fig. 7,a). The latter three are from three different cups.

Stoneware from the site includes a sherd from a jar glazed on the outside with a salt glaze and on the inside with a Leon slip used by the Meyer pottery in Atascosa, Texas (Fig. 7,h). This would probably have been made sometime between 1887 and 1895 (Greer and Black 1971:1-5). Another stoneware sherd from a vessel of similar diameter is somewhat later, having a Bristol glaze on the outside and an Albany slip on the inside. The third piece of stoneware is from a heavy, creamy white bowl-shaped vessel with a rounded rim. All of these sherds came from the Trench $\mathrm{C}$ deposits.

\section{GLASS}

Glass fragments recovered during the excavations range from sherds of a 19th-century pale green, hand-blown wine bottle (Fig. 7,g) to 20th-century bright green soft drink bottles. The former came from the same location as the blue edgeware sherd, while the latter were found in the demolition rubble of the brick building and at the deeper levels at the west end of Trench C. A whole olive oil bottle (Wilson 1981:90) also came from the west end of Trench $\mathrm{C}$, as did milk bottle and brown beer, whiskey, and bitters bottle fragments. Tiny pieces of red and blue glass and two pieces of an aqua glass insulator came from Trench $A$.

\section{ANIMAL BONE}

The few fragments of bone recovered that are identifiable are from standard cuts of beef, pork, and chicken. There are saw cuts on a number of the bones.

\section{METAL OBJECTS}

A number of metal objects, probably resulting from barn or workshop activities, were recovered during excavations. Metal scrap, fragments of strapping, a brass nut, and a threaded iron rod that appears to come from some sort of machinery were found in Trenches A and B. A horseshoe and an unidentified object formed from one continuous iron rod came from Trench C.

\section{BUILDING MATERIALS}

Building materials from the test trenches for the most part can be dated to the late 19th and early 20th centuries. Of nine nails recovered, only two are square or cut nails that might represent the Mojaras house.

All the flat glass from the site is $3 / 32$ of an inch or more in thickness. Walker (1971:78) concludes, based on comparison of a large number of site reports, that there should be no glass thinner than $2 / 32$ of an inch on a site dating 
after 1845. All of the window glass recovered is pale aqua in tint, bearing out Miller's (1960) observation that later 19 th-century window glass is greenish in appearance.

Fragments of yellow brick from which the two-story building was constructed were plentiful in the demolition debris. This brick closely resembles brick shipped to San Antonio from Laredo during the last quarter of the 19th century, but no stamped labels were found. Apparently some later brick additions were made to the building, since red brick fragments stamped "D'HANIS" were recovered from the demolition debris in Trench A. The D'Hanis brick factory did not stamp its bricks until 1905 (Fox 1978b:11). Also indicating later additions are pieces of red hollow tile from Trenches A and B. Samples of sand and lime mortar and painted plaster were recovered from all of the trenches. These bear traces of several colors indicating rooms painted in pink, blue, and green, as well as white.

Other materials recovered include fragments of a composition roofing or flooring material, a piece of slate $3 / 16$ of an inch thick, a porcelain insulator for installation of electric wiring, and a fragment of a porcelain light fixture. Pieces of glazed and unglazed sewer tile were found in all trenches, an indication of the amount of utility trenching that has been done across this lot in the past.

\section{CONCLUSIONS}

Trench A and the eastern portion of Trench C failed to locate any in situ remains of the foundation of the Mojaras house, although a number of shaped limestone blocks found during the trenching may have been from that structure. The foundations of the house were probably disturbed during demolition and preparation of the lot for construction of the next building. It was also apparent from the two east-west trenches across the entire back yard that the area had been severely disturbed by the demolition of the buildings and the installation of pipe trenches, and that it was extremely unlikely that any utilitarian features or structures related to the Mojaras occupation could have survived.

Trench $\mathrm{C}$, at its west end, explored the area suspected to include the east bank of the acequia. It revealed a thoroughly disturbed situation and no really firm answer as to the location of the acequia.

The north end of Trench A and the east end of Trench B revealed the remains of the foundations of the two-story brick building are still in place. After analysis of the construction of these foundations, we conclude that this building was probably constructed in the 1870 s, before the carriage maker and blacksmith Eckenroth occupied the premises.

\section{RECOMMENDATIONS}

As stated in the Introduction, this site is due to be completely removed to a depth of 20 feet or more. Since there does not appear to be any remains of the Mojaras house still undisturbed and we found no sign of undisturbed trash deposits in relation to either of the structures, we do not recommend further work at this location. We also see no reason to recommend monitoring of the excavation of the parking garage. Members of the CAR staff will be on call and in touch with the contractor in case any unexpected archaeological or architectural remains are uncovered. No further historical, architectural, or archaeological information is expected to be present on the site. Therefore we do not recommend a determination of eligibility for listing on the National Register of Historic Places or consideration of the site for a State Archeological Landmark. 


\section{REFERENCES CITED}

Arneson, E.

1921 Early Irrigation in Texas. Southwestern Historical Quarterly XXV:121-130.

Baumburger, C.

n.d. Some History of Early Pioneer Days of the Cement Industry in West Texas. Copy in library of San Antonio Museum Association.

Bexar County

Bexar County Deed Records (BCDR)

Originals and microfilm in Bexar County Courthouse, San Antonio, Texas.

Spanish Archives

Originals in County Archives, Bexar County Courthouse, San Antonio, Texas.

Brown, K. M.

1986 Structure and Stratigraphy of the Site. In La Villita Earthworks (41 BX 677): San Antonio, Texas, assembled by J. H. Labadie:28-61. Center for Archaeological Research, The University of Texas at San Antonio, Archaeological Survey Report 159.

Buck, S. M.

1980 Yanaguana's Successors. The Story of the Canary Islanders' Immigration into Texas in the Eighteenth Century. Commemorative Edition. Robert M. Benavides, San Antonio. Originally published in 1949 by Naylor Publishing Company, San Antonio.

Chabot, F. C.

1937 With the Makers of San Antonio. Privately published, San Antonio, Texas.

City Directories

1877- Located at San Antonio Public Main Library, San Antonio, Texas.

1960

City of San Antonio

City Council Minutes (CCM)

Originals at City Hall, San Antonio, Texas.

City Public Service Board

1958 Letter to E. Leg Keefe, Mutual Insurance Agency, October 31. In Right-of-Way File, City Public Service, San Antonio, Texas. 
Corner, W.

1890 San Antonio de Bexar: A Guide and History. Bainbridge and Corner, San Antonio, Texas.

Ellis, W. B.

1986 Preliminary Archaeological Assessment of the Northeast Parking Lot Area (Phase III) Site of the New Bexar County Justice Center, San Antonio, Texas. Center for Archaeological Research, The University of Texas at San Antonio. Draft report submitted to County Commissioners.

Fox, A. A.

1978a Preliminary Archaeological Assessment of South Parking Lot Area (Phase I), Site of Courthouse Annex, San Antonio, Texas. Center for Archaeological Research, The University of Texas at San Antonio. Draft report submitted to County Commissioners.

1978b Archaeological Investigations of Portions of the San Pedro and Alazan Acequias in San Antonio, Texas. Center for Archaeological Research, The University of Texas at San Antonio, Archaeological Survey Report 49.

1986 Ceramics. In La Villita Earthworks (41 BX 677): San Antonio, Texas, assembled by J. H. Labadie:107-127. Center for Archaeological Research, The University of Texas at San Antonio, Archaeological Survey Report 159.

Fox, D. E., F. Valdez, Jr., and L. O. Bobbitt

1978 The Dolores Aldrete House Property, San Antonio, Texas. Center for Archaeological Research, The University of Texas at San Antonio, Archaeological Survey Report 58.

Greer, G. H. and H. Black

1971 The Meyer Family: Master Potters of Texas. Trinity University Press, San Antonio.

Ivey, J. E.

1978 Archaeological Investigations at the Gresser House (41 BX 369), San Antonio, Texas. Center for Archaeological Research, The University of Texas at San Antonio, Archaeological Survey Report 60 .

Katz, P. R.

1978 Archaeological and Historical Investigations in the Arciniega Street Area, Downtown San Antonio, Texas. Center for Archaeological Research, The University of Texas at San Antonio, Archaeological Survey Report 61.

Labadie, J. H., assembler

1986 La Villita Earthworks (41 BX 677): San Antonio, Texas. Center for Archaeological Research, The University of Texas at San Antonio, Archaeological Survey Report 159.

Miller, C. F.

1960 The Excavation and Investigation of Fort Lookout Trading Post II (Site 39LM57) in the Fort Randall Reservoir, South Dakota. Bureau of American Ethnology, Bulletin 176:49-82. Washington, D.C. 
Ramsdell, C.

1976 San Antonio, A Historical and Pictorial Guide. Revised edition by Carmen Perry. Originally published in 1959. University of Texas Press, Austin.

Sanborn Map and Publishing Company, Ltd.

1904 Map of San Antonio, Texas. Rare Book Collection, Trinity University, San Antonio.

Schuchard, E.

1951 100th Anniversary, Pioneer Flour Mills, San Antonio, Texas, 1851-1951. Naylor Publishing Company, San Antonio.

Schuetz, M. K.

1970 The Cuarteles of San Antonio de Bexar. Unpublished manuscript. Copy on file, Center for Archaeological Research, The University of Texas at San Antonio.

Taylor, F. B., R. B. Hailey, and D. L. Richmond

1966 Soil Survey, Bexar County, Texas. U.S. Department of Agriculture, Soil Conservation Service in cooperation with Texas Agricultural Experiment Station, Series 1962(12).

United States Department of the Interior, Office of the Census (USDI-OC)

1850 The Seventh Census, 1850. Retums of Schedule One, Population.

Walker, J. W.

1971 Excavation of the Arkansas Post Branch of the Bank of the State of Arkansas, Arkansas Post National Memorial, Arkansas. Southeast Archeological Center, National Park Service, Tallahassee, Florida.

Wilson, $\mathbf{R}$.

1981 Bottles on the Western Frontier. The University of Arizona Press in collaboration with the Southwest Parks and Monuments Association, Tucson, Arizona. 



